Article

\title{
3-Ishwarone, a Rare Ishwarane Sesquiterpene from Peperomia scandens Ruiz \& Pavon: Structural Elucidation through a Joint Experimental and Theoretical Study
}

Fernando M. dos S. Junior ${ }^{1}$, Leosvaldo S. M. Velozo ${ }^{1}$, Erika M. de Carvalho ${ }^{2}$,

André M. Marques ${ }^{1}$, Ricardo M. Borges ${ }^{1}$, Ana Paula F. Trindade ${ }^{1}$, Maria Isabel S. dos Santos ${ }^{3}$, Ana Carolina F. de Albuquerque ${ }^{1}$, Fabio L.P. Costa ${ }^{1}$, Maria Auxiliadora C. Kaplan ${ }^{1}$ and Mauro B. de Amorim ${ }^{1, *}$

1 Núcleo de Pesquisas de Produtos Naturais, Universidade Federal do Rio de Janeiro, Rio de Janeiro, RJ, 21941-902, Brazil; E-Mails: fernandonppn@gmail.com (F.M.S.J.); velozo72@hotmail.com (L.S.M.V.); andrefarmaciarj@yahoo.com.br (A.M.M.); ricardo_mborges@nppn.ufrj.br (R.M.B.); nanda.20@ig.com.br (A.P.F.T.); anacarol_albuquerque@ hotmail.com (A.C.F.A.); fabbioquimica@gmail.com (F.L.P.C.); makaplan@uol.com.br (M.A.C.K.); mbamorim@nppn.ufrj.br (M.B.A.)

2 Instituto de Tecnologia em Fármacos, FAR-MANGUINHOS, Fiocruz, Rio de Janeiro, RJ, 22775-903, Brazil; E-Mail: erikamc@far.fiocruz.br

3 Departamento de Produtos Naturais e Alimentos, Faculdade de Farmácia, Universidade Federal do Rio de Janeiro, 21941-590, Rio de Janeiro, RJ, Brazil; E-Mail: sampaio@pharma.ufrj.br

* Author to whom correspondence should be addressed; E-Mail: mbamorim@nppn.ufrj.br; Tel.: +55-21-2562-6792; Fax: +55-21-2562-6512.

Received: 12 September 2013; in revised form: 24 October 2013 / Accepted: 29 October 2013 / Published: 31 October 2013

Abstract: 3-Ishwarone, (1), a sesquiterpene with a rare ishwarane skeleton, was isolated from Peperomia scandens Ruiz \& Pavon (Piperaceae). Its structure was unambiguously determined by 1D- and 2D-NMR and infrared analyses, as well as by comparative theoretical studies which involved calculations of ${ }^{13} \mathrm{C}-\mathrm{NMR}$ chemical shifts, using the Density Functional Theory (DFT) with the mPW1PW91 hybrid functional and Pople's 6-31G(d) basis set, and of vibrational frequencies, using the B3LYP hybrid functional and triple $\zeta$ Dunning's correlation consistent basis set (cc-pVTZ), of (1) and three of its possible diastereomers, compounds 2-4. 
Keywords: 3-ishwarone; structure elucidation; IR spectra simulation; NMR chemical shift calculation; molecular modeling

\section{Introduction}

Peperomia is the second largest genus of the Piperaceae family, comprising about 1,500-1,700 species, which are found in tropical regions throughout the World [1]. Although few representative species have been analyzed on the chemical point of view, Peperomia genus has been reported to be also the second most abundant source of bioactive compounds within the Piperaceae family [2]. Phytochemical investigations have led into the isolation of many special metabolites such as acylcyclohexane-1,3-diones, alkaloids, cinnamic acid derivatives, chromanes, chromenes, chromones, aldehydes, lignoids, flavonoids, meroterpenes, phenylpropanoids, phenols, polyketides, quinones, secolignans and sesquiterpenes [3-8]. Thus, probably for that reason, many of these plants have been used in folk medicine to treat many conditions [9,10]. Peperomia scandens, popularly known as German peperomia ("alemã") or false philodendron, is an herbaceous perennial and succulent herb, which is native to the Caribbean, Mexico, and Central America [11]. P. scandens is well distributed in Rio de Janeiro city, easily found in public markets for sale and commonly used for ornamental purposes.

In this work, we report the isolation from the fresh aerial parts of P. scandens Ruiz \& Pavon of the rare but already known sequiterpene 3-ishwarone (1, Figure 1) [12]. Its structure was unambiguously determined by usual analysis of experimental data and from theoretical simulations of its ${ }^{13} \mathrm{C}-\mathrm{NMR}$ and IR spectra.

Figure 1. Four possible diastereomers of 3-ishwarone, $(1 R, 2 S, 4 S, 5 R, 9 R, 11 R)$-3-ishwarone (configuration 1, the same stereochemistry proposed by Lago et al. [12]), $(1 R, 2 S, 4 S, 5 S, 9 R, 11 R)$-3-ishwarone (configuration 2$),(1 R, 2 S, 4 R, 5 R, 9 R, 11 R)$-3-ishwarone (configuration 3 ) and $(1 R, 2 S, 4 R, 5 S, 9 R, 11 R)$-3-ishwarone (configuration 4$)$, respectively.

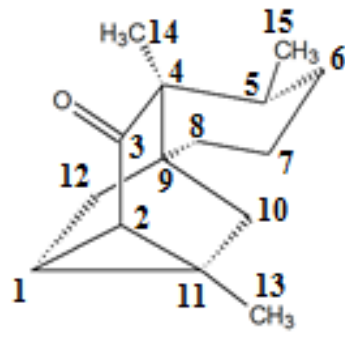

1

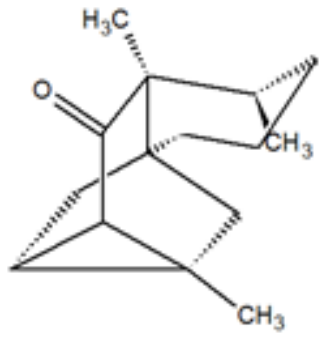

2

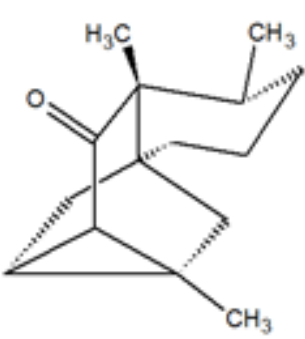

3

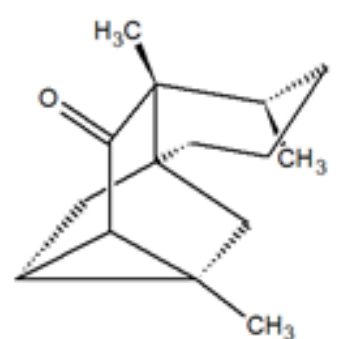

4

\section{Results and Discussion}

Compound 1 was isolated as a white amorphous solid, whose molecular formula was defined as $\mathrm{C}_{15} \mathrm{H}_{22} \mathrm{O}$ based on $\left([\mathrm{M}]^{+} \mathrm{m} / z 218\right)$ by LREIMS. The calculated hydrogen deficiency index of 5 and the absence of olefinic carbons suggested the presence of a tetracyclic skeleton compound. Due to the excess of overlapping signals between $\delta 1.15-1.67 \mathrm{ppm}$ and at $\delta$ 1.86-1.97 ppm in the ${ }^{1} \mathrm{H}-\mathrm{NMR}$ 
spectrum in $\mathrm{CDCl}_{3}$, both carbon and hydrogen NMR spectra were also record at $\mathrm{C}_{6} \mathrm{D}_{6}$ and compared to the literature data [12]. Like the known 3-ishwarone, its ${ }^{1} \mathrm{H}$ - and ${ }^{13} \mathrm{C}-\mathrm{NMR}$ spectra (Table 1) showed signals related to fifteen carbon atoms, attributable to three methyls, five methylenes, three methines, three quaternary carbons and one carbonyl group.

To reliably assign the ${ }^{1} \mathrm{H}-\mathrm{NMR}$ spectra of the compound 1, 2D experiments such as COSY, HSQC, $\mathrm{HMBC}$ were carried out as the methylene group doublets at $\delta 1.99 \mathrm{ppm}(J=12.3 \mathrm{~Hz})$ and at $\delta 1.66 \mathrm{ppm}$ $(J=12.4 \mathrm{~Hz})$ were assigned as $\mathrm{H}-10 \mathrm{a}$ and $\mathrm{H}-12 \mathrm{~b}$, respectively. Due to the several overlapping regions between $0.85-1.40 \mathrm{ppm}$ in the ${ }^{1} \mathrm{H}-\mathrm{NMR}$ spectrum, some of the overlapped methylene hydrogen multiplets were only assigned by using $2 \mathrm{D}$ techniques as shown in the Table 1.

Table 1. ${ }^{1} \mathrm{H}$ and ${ }^{13} \mathrm{C}-\mathrm{NMR}$ spectral data $(\delta / \mathrm{ppm})$ for 3-ishwarone in $\mathrm{C}_{6} \mathrm{D}_{6}$ and $\mathrm{CDCl}_{3}$.

\begin{tabular}{|c|c|c|c|c|c|c|}
\hline \multirow{2}{*}{$\begin{array}{c}\text { Atom } \\
\text { number }\end{array}$} & \multicolumn{4}{|c|}{$\mathrm{C}_{6} \mathrm{D}_{6}$} & \multicolumn{2}{|l|}{$\mathrm{CDCl}_{3}$} \\
\hline & $\delta{ }^{1} \mathrm{H}$ (multiplicity, $J / \mathrm{Hz}$ ) & $\delta^{13} \mathbf{C}^{\mathrm{a}}$ & $\delta^{13} \mathrm{C}^{\mathrm{b}}$ & NOESY & $\delta{ }^{1} \mathrm{H}$ (multiplicity, J/Hz) & $\delta^{13} \mathrm{C}$ \\
\hline 1 & $1.14(1 \mathrm{H}, \mathrm{dd}, J=7.2$ and $2.8 \mathrm{~Hz})$ & $29.7(1)$ & 29.9 & -- & $1.64(1 \mathrm{H}, \mathrm{dd}, J=3,8$ and $9,0 \mathrm{~Hz})$ & 30.5 \\
\hline 2 & $1.53(1 \mathrm{H}, \mathrm{d}, J=7.3 \mathrm{~Hz})$ & $37.9(1)$ & 37.9 & -- & $1.51(1 \mathrm{H}, \mathrm{d}, J=2,8 \mathrm{~Hz})$ & 38.2 \\
\hline 3 & -- & $212.5(4)$ & 213.4 & -- & -- & 215.0 \\
\hline 4 & -- & $49.3(0)$ & 49.9 & -- & -- & 49.3 \\
\hline 5 & $\begin{array}{c}1.77(1 \mathrm{H}, \mathrm{dqd}, J=18.7,6.6 \text { and } \\
3.9 \mathrm{~Hz})\end{array}$ & $31.7(1)$ & 31.8 & H-15 & 1.91 (1H. m) & 31.3 \\
\hline 6 & $\begin{array}{l}\text { a: } 1.05-1.01(1 \mathrm{H}, \mathrm{m}) \\
\text { b: } 1.24-1.17(1 \mathrm{H}, \mathrm{m})\end{array}$ & $31.5(2)$ & 31.5 & -- & $\begin{array}{l}\text { a: } 1.38(1 \mathrm{H}, \mathrm{m}) \\
\text { b: } 1.22(1 \mathrm{H}, \mathrm{m})\end{array}$ & 31.1 \\
\hline 7 & $\begin{array}{l}\text { a: } 1.24-1.21(1 \mathrm{H}, \mathrm{m}) \\
\text { b: } 1.35-1.31(1 \mathrm{H}, \mathrm{m})\end{array}$ & $23.5(2)$ & 23.6 & -- & $\begin{array}{l}\text { a: } 1.54(1 \mathrm{H}, \mathrm{m}) \\
\text { b: } 1.40(1 \mathrm{H}, \mathrm{m})\end{array}$ & 23.1 \\
\hline 8 & $\begin{array}{c}\text { a: } 0.89(1 \mathrm{H}, \mathrm{m}) \\
\text { b: } 1.39-1.35(1 \mathrm{H}, \mathrm{m})\end{array}$ & $32.2(2)$ & 32.2 & $\begin{array}{l}\mathrm{H}-8 \mathrm{~b} \\
\mathrm{H}-8 \mathrm{a}\end{array}$ & $\begin{array}{l}\text { a: } 1.60(1 \mathrm{H}, \mathrm{m}) \\
\text { b: } 1.19(1 \mathrm{H}, \mathrm{m})\end{array}$ & 31.9 \\
\hline 9 & -- & $43.0(0)$ & 43.1 & -- & -- & 42.9 \\
\hline 10 & $\begin{array}{l}\text { a: } 1.99(1 \mathrm{H}, \mathrm{d}, J=12.3 \mathrm{~Hz}) \\
\text { b: } 0.93(1 \mathrm{H}, \mathrm{d}, J=12.3 \mathrm{~Hz})\end{array}$ & $39.5(2)$ & 39.5 & $\begin{array}{l}\mathrm{H}-10 \mathrm{a} \\
\mathrm{H}-10 \mathrm{~b}\end{array}$ & $\begin{array}{l}\text { a: } 2.27(1 \mathrm{H}, \mathrm{d}, J=12,39 \mathrm{~Hz}) \\
\text { b: } 1.35(1 \mathrm{H}, \mathrm{d}, J=12,31 \mathrm{~Hz})\end{array}$ & 39.5 \\
\hline 11 & -- & $29.8(0)$ & 30.0 & -- & -- & 30.8 \\
\hline 12 & $\begin{array}{c}\text { a: } 1.10(1 \mathrm{H}, \mathrm{dd}, J=12.4,2.6 \mathrm{~Hz}) \\
\text { b: } 1.66(1 \mathrm{H}, \mathrm{d}, J=12.4 \mathrm{~Hz})\end{array}$ & $35.1(2)$ & 35.1 & $\begin{array}{c}\mathrm{H}-12 \mathrm{~b} \\
\mathrm{H}-12 \mathrm{a} ; \mathrm{H}- \\
14\end{array}$ & $\begin{array}{l}\text { a: } 1.91(1 \mathrm{H}, \mathrm{d}, J=12,72 \mathrm{~Hz}) \\
\text { b: } 1.49(1 \mathrm{H}, \mathrm{d}, J=12,14 \mathrm{~Hz})\end{array}$ & 34.9 \\
\hline 13 & $0.95(3 \mathrm{H}, \mathrm{s})$ & $19.4(3)$ & 19.5 & -- & $1.29(3 \mathrm{H}, \mathrm{s})$ & 19.5 \\
\hline 14 & $0.89(3 \mathrm{H}, \mathrm{s})$ & $11.8(3)$ & 12.0 & $\mathrm{H}-12 \mathrm{~b}$ & $0.91(3 \mathrm{H}, \mathrm{s})$ & 11.5 \\
\hline 15 & $1.27(3 \mathrm{H}, \mathrm{d}, J=6.7 \mathrm{~Hz})$ & $17.5(3)$ & 17.7 & $\mathrm{H}-15$ & $1.05(3 \mathrm{H}, \mathrm{d}, J=6,6 \mathrm{~Hz})$ & 17.1 \\
\hline
\end{tabular}

The four quaternary carbon atoms and the carbonyl group positions were suggested by the 2D spectra correlations. The absence of hydrogen bearing carbon atoms in the HSQC associated to the HMBC long range correlations determined the position of the quaternary carbon atoms in the structure. The HMBC correlations between H-14 and C-3, C-4 at $\delta 212.5$ and $\delta 49.3$ ppm, respectively, as well as between $\mathrm{H}-1$ and $\mathrm{C}-3$ supported the carbonyl C-3 assignment. The NOESY space correlations between $\mathrm{H} 14$ and $\mathrm{H} 12 \mathrm{~b}$ suggests that relative stereochemistry for this molecule is the same proposed 
for 3-ishwarone; however, the NOESY sensibility for this space correlation is quite low (see Supplementary Materials) so that it seems appropriate to obtain further information to confirm the relative configuration for this molecule. In order to confirm the relative stereochemistry attributed to this product and its identity with 3-ishwarone (1), isolated for the first time from the leaves of $P$. oreophila Hensch (Piperaceae) by Lago and Co-workers [12] two additional studies were performed: comparisons of the theoretically calculated ${ }^{13} \mathrm{C}-\mathrm{NMR}$ and (fingerprint region) infrared spectra for the four diastereomers of 3-ishwarone generated by configuration inversions at carbons 4 and 5 (Figure 1) with those obtained experimentally. As far as we know the successful use of such a joint methodology has never been used in elucidating structures of such a class of sesquiterpenes [13].

It must be stressed that in doing so we aim to find out if these configuration inversions can or cannot induce easily observable changes in both ${ }^{13} \mathrm{C}-\mathrm{NMR}$ and IR spectra and thereby avoid incorrect assignment of relative configurations. As the first step of both studies, the conformationally rigid structures of these diastereomers were constructed and had their geometries optimized (with MMFF94 force-field) using the free molecular editor and visualizer program Avogadro v.1.1.0 [14]. These geometries were then re-optimized and submitted to ${ }^{13} \mathrm{C}-\mathrm{NMR}$ and IR calculations using Density Functional Theory (DFT) with the GAUSSIAN09 series of programs [15] as described in the following paragraphs.

The ${ }^{13} \mathrm{C}$ chemical shift calculations were performed by a Gauge Included Atomic Orbitals-Hybrid Density Functional Theory (GIAO-HDFT) scaling factor calculation procedure previously published by some of us [16] at the GIAO/mPW1PW91/6-31G(d)//mPW1PW91/6-31G(d) [17] level of theory: namely geometry optimizations using the Perdew-Wang 1991 exchange functional as modified by Adamo and Barone combined with Perdew and Wang's 1991 gradient-corrected correlation functional $[18,19]$, with the 6-31G(d) Pople basis set [20], followed by absolute isotropic ${ }^{13} \mathrm{C}$ magnetic shielding constants calculations for the four diastereomers $\left(\sigma_{\mathrm{i}}, \mathrm{i}=1\right.$ to 15$)$ and TMS $\left(\sigma_{0}\right)$ as internal reference using GIAO approximation at the same level of theory (GIAO/mPW1PW91/6-31G(d)). The predicted ${ }^{13} \mathrm{C}-\mathrm{NMR}$ chemical shifts, $\delta_{i}=\sigma_{0}-\sigma_{i}$, were then scaled by a factor obtained from linear correlation between the calculated and experimental chemical shifts of a pool of adequately chosen compounds [21], as $\delta_{\text {scal }}=\mathrm{a} \times$ $\delta_{\mathrm{i}}+\mathrm{b}$. Comparison of the theoretical ${ }^{13} \mathrm{C}$ chemical shifts obtained for the four possible diastereomers of 3-ishwarone with experimental data (Table 2) shows mean absolute (MAD) and root-mean-square (RMSD) deviations which allows discarding the diastereomers 2 and 3, these deviations came principally from carbon 5 and methyls 14 and 15, which are directly involved at configuration inversions.

Table 2. Comparison of the theoretical ${ }^{13} \mathrm{C}-\mathrm{NMR}$ chemical shifts for the four possible diastereomers of 3-ishwarone with experimental data:

\begin{tabular}{cccccc}
\hline $\begin{array}{c}\text { Atom } \\
\text { number }\end{array}$ & $\begin{array}{c}\text { Conf. 1 } \\
\boldsymbol{\delta}_{\text {esc }}\end{array}$ & $\begin{array}{c}\text { Conf. 2 } \\
\boldsymbol{\delta}_{\text {esc }}\end{array}$ & $\begin{array}{c}\text { Conf. 3 } \\
\boldsymbol{\delta}_{\text {esc }}\end{array}$ & $\begin{array}{c}\text { Conf. 4 } \\
\boldsymbol{\delta}_{\text {esc }}\end{array}$ & EXP \\
\hline $\mathbf{1}$ & 30,69 & 29,54 & 31,05 & 30,43 & $\mathbf{3 0 , 4}$ \\
$\mathbf{2}$ & 38,10 & 36,57 & 36,74 & 38,24 & $\mathbf{3 8 , 1}$ \\
$\mathbf{3}$ & 212,46 & 211,57 & 211,70 & 212,35 & $\mathbf{2 1 5}$ \\
$\mathbf{4}$ & 49,94 & 50,18 & 50,25 & 50,04 & $\mathbf{4 9 , 3}$ \\
$\mathbf{5}$ & 32,76 & 37,42 & 37,60 & 32,70 & $\mathbf{3 1 , 3}$ \\
\hline
\end{tabular}


Table 2. Cont.

\begin{tabular}{cccccc}
\hline $\begin{array}{c}\text { Atom } \\
\text { number }\end{array}$ & $\begin{array}{c}\text { Conf. } \mathbf{1} \\
\boldsymbol{\delta}_{\text {esc }}\end{array}$ & $\begin{array}{c}\text { Conf. } 2 \\
\boldsymbol{\delta}_{\text {esc }}\end{array}$ & $\begin{array}{c}\text { Conf. } \mathbf{3} \\
\boldsymbol{\delta}_{\text {esc }}\end{array}$ & $\begin{array}{c}\text { Conf. } \mathbf{4} \\
\boldsymbol{\delta}_{\text {esc }}\end{array}$ & EXP \\
\hline $\mathbf{6}$ & 31,17 & 27,82 & 27,84 & 31,10 & $\mathbf{3 1 , 1}$ \\
$\mathbf{7}$ & 24,09 & 20,27 & 20,18 & 23,94 & $\mathbf{2 3 , 1}$ \\
$\mathbf{8}$ & 33,20 & 33,50 & 33,33 & 33,06 & $\mathbf{3 1 , 9}$ \\
$\mathbf{9}$ & 42,45 & 40,64 & 40,78 & 42,48 & $\mathbf{4 2 , 9}$ \\
$\mathbf{1 0}$ & 39,68 & 41,41 & 42,53 & 41,03 & $\mathbf{3 9 , 5}$ \\
$\mathbf{1 1}$ & 30,63 & 31,23 & 29,81 & 31,09 & $\mathbf{3 0 , 8}$ \\
$\mathbf{1 2}$ & 35,98 & 37,38 & 36,47 & 34,57 & $\mathbf{3 4 , 9}$ \\
$\mathbf{1 3}$ & 20,51 & 20,66 & 20,61 & 20,51 & $\mathbf{1 9 , 5}$ \\
$\mathbf{1 4}$ & 13,62 & 23,72 & 23,63 & 13,67 & $\mathbf{1 1 , 5}$ \\
$\mathbf{1 5}$ & 17,38 & 19,45 & 19,50 & 17,35 & $\mathbf{1 7 , 1}$ \\
$\mathbf{M A D}$ & 0,84 & 2,89 & 2,90 & 0,86 & \\
$\mathbf{R M S}$ & 1,12 & 4,05 & 4,05 & 1,16 & \\
\hline
\end{tabular}

Next we consider the comparison of the (fingerprint region) infrared spectrum obtained experimentally for the 3-ishwarone, in $\mathrm{CHCl}_{3}$ solution, with those simulated theoretically for the four diastereomers previously analyzed (Figures 2 and 3). Vibrational frequencies were calculated through Density Functional Theory (DFT) model using the B3LYP, Beck's three-parameter hybrid functional [22] which uses the non-local correlation provided by LYP functional [23] and VWN functional III for local correlation [24], with cc-pVTZ Dunning's correlation consistent triple-zeta basis set [25], and corrected by an appropriated scaling factor [26]. Infrared spectra were simulated using Lorentzian band shapes and appropriate band width $\left(5-10 \mathrm{~cm}^{-1}\right)$ as follows [27]:

$$
\varepsilon(v)=\frac{\Delta^{2}}{\Delta^{2}+\left(v-v_{0}\right)^{2}} \varepsilon_{0}
$$

Comparison of the theoretical (fingerprint region) infrared spectra obtained for the four possible diastereomers of 3-ishwarone with experimental data (Figures 2, 3, and Table 3) shows that configuration 1 has the best agreement with experimental data. Note that the main differences between the vibrational frequencies are in the region at $800-900 \mathrm{~cm}^{-1}$, arising from normal modes of vibration of the methyls 14 and 15 (see Supplementary Materials).

Figure 2. Simulated infrared spectra (fingerprint region) of the four possible diastereomers of 3-ishwarone.

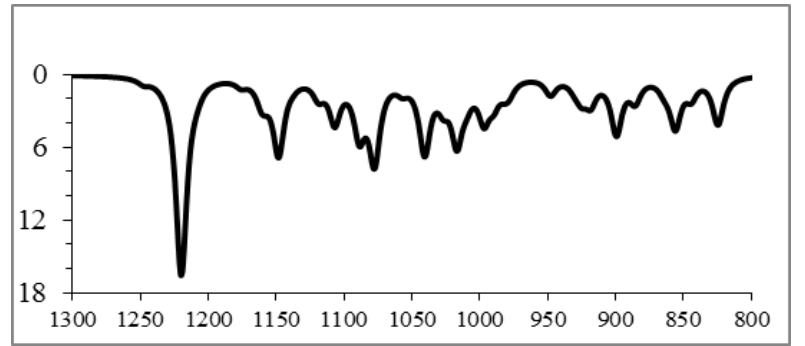

Configuration 1

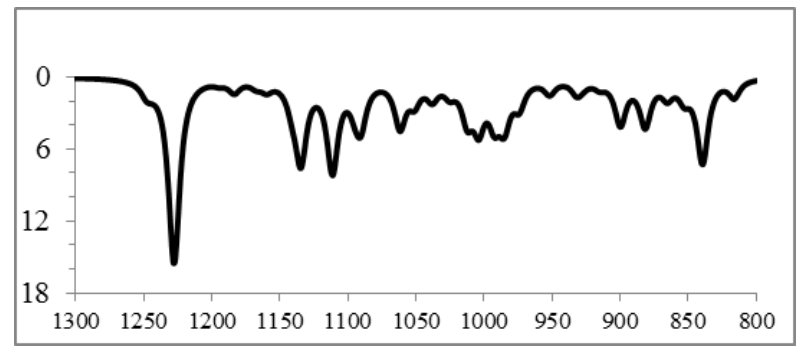

Configuration 2 
Figure 2. Cont.

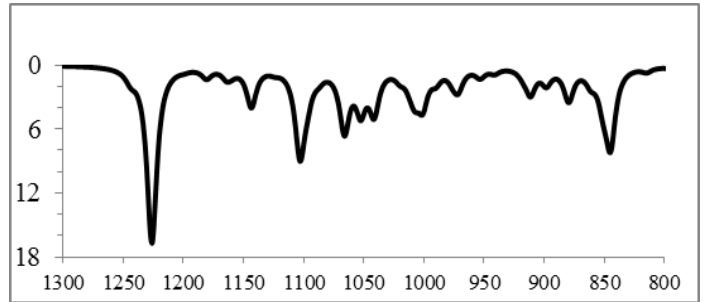

Configuration 3

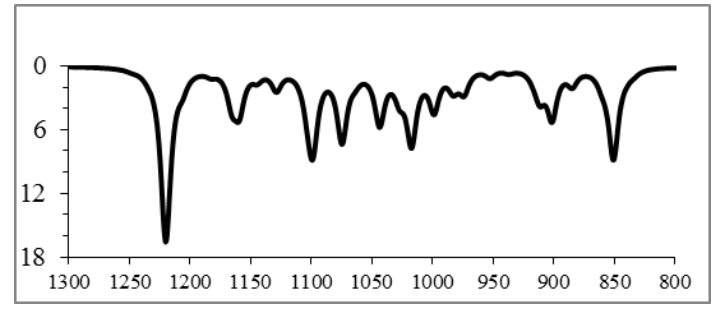

Configuration 4

Figure 3. Comparison of the superposition of simulated infrared spectra (fingerprint region) of diastereomers 1 (blue) and 4 (red) (bottom) with experimental data (top).

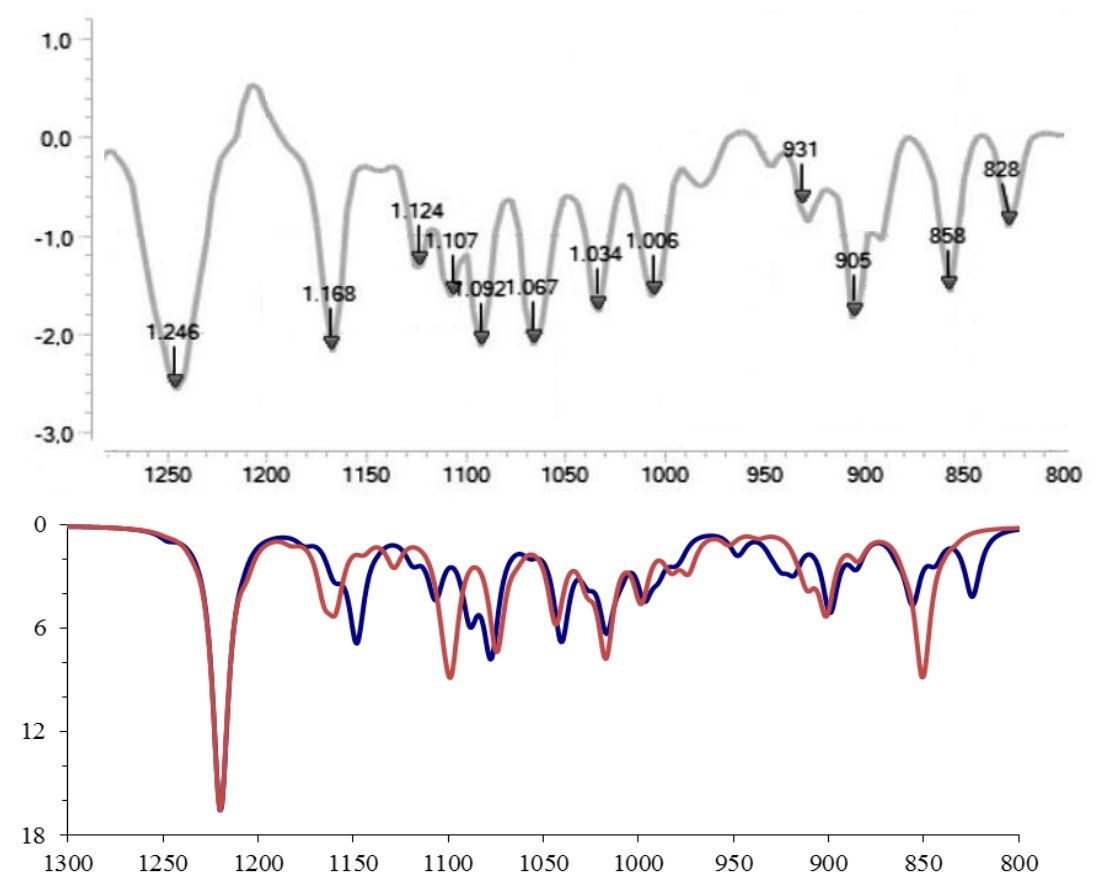

Table 3. Comparison of the fingerprint vibrational frequencies obtained theoretically (configuration 1) and experimentally for 3-Ishwarone:

\begin{tabular}{ccc}
\hline Exp. $\left(\mathbf{c m}^{\mathbf{- 1}}\right)$ & Theor. $\left(\mathbf{c m}^{\mathbf{- 1}}\right)$ & $\boldsymbol{A}_{\text {teor-exp }}\left(\mathbf{c m}^{\mathbf{- 1}}\right)^{\mathbf{a}}$ \\
\hline 828 & 824 & $4[0,5]$ \\
858 & 856 & $2[0,2]$ \\
905 & 899 & $6[0,6]$ \\
931 & 930 & $1[0,1]$ \\
1006 & 997 & $9[0,9]$ \\
1034 & 1017 & $17[1,6]$ \\
1067 & 1040 & $27[2,5]$ \\
1092 & 1078 & $14[1,3]$ \\
1107 & 1089 & $18[1,6]$ \\
1124 & 1107 & $17[1,5]$ \\
1168 & 1148 & $20[1,7]$ \\
1246 & 1220 & $26[1,2]$ \\
& MAD $=$ & $13[1,2]$
\end{tabular}

${ }^{a}$ values in brackets presents the percentage deviation in relation to calculated value. 


\section{Experimental}

\subsection{General}

Sílica gel (230-400 mesh, Merck, Darmstadt, Germany) was used for column chromatographic separations while silica gel 60 PF254 (Merck) was used for analytical TLC.

\subsection{GC-FID Analysis}

Qualitative and quantitative analysis were carried out on a GC-MS-QP2010 PLUS Shimadzu apparatus (Shimadzu, Kyoto, Japan) with a DB-1MS fused silica capillary column $(30 \mathrm{~m} \times 0.25 \mathrm{~mm} \times$ $0.25 \mu \mathrm{m}$ film thickness). The operating temperatures used were: injector $260{ }^{\circ} \mathrm{C}$, detector $290{ }^{\circ} \mathrm{C}$ and column oven $60{ }^{\circ} \mathrm{C}$ up to $290{ }^{\circ} \mathrm{C}\left(3{ }^{\circ} \mathrm{C} / \mathrm{min}\right)$. Helium at $1.0 \mathrm{~mL} \mathrm{~min}{ }^{-1}$ was used as a carried gas. The percentages of the compounds were obtained by GC- FID analysis.

\subsection{GC-MS Analysis}

Qualitative analysis was carried out on a GC-MS QP 5000 Shimadzu instrument with a ZB-5MS fused silica capillary column $(30 \mathrm{~m} \times 0.25 \mathrm{~mm} \times 0.25 \mu \mathrm{m}$ film thickness $)$ under the experimental conditions recorded for GC-FID analysis.

\subsection{NMR Measurements}

The NMR spectra were recorded on a Brüker AVANCE-400 (400 MHz for ${ }^{1} \mathrm{H}$ and $100 \mathrm{MHz}$ for ${ }^{13} \mathrm{C}$ ) spectrometer (Brüker Spectrospin, Billerica, MA, USA) using $5 \mathrm{~mm}$ sample tubes, chloroform-d and benzene- $\mathrm{d}_{6}(99.9 \% \mathrm{D}, \mathrm{CIL}$, Tewksbury, MA, USA) as solvents. The chemical shifts were expressed relative to TMS. The chemical shifts are expressed as $\delta$ values in parts per million (ppm) and the coupling constants $(J)$ are given in hertz $(\mathrm{Hz})$. The $2 \mathrm{D}$ experiments $\left({ }^{1} \mathrm{H}-{ }^{1} \mathrm{H}\right.$ COSY, HSQC, HMBC, NOESY) were performed using standard Brüker micro programs. Gradient selections were used in all 2D techniques.

\subsection{INFRARED Measurements}

Infrared analyses were carried out on a ReactIR 15 (Mettler Toledo, Columbus, OH, USA) FTIRATR spectrophotometer with Attenuated Total Reflectance (ATR) technique, using a $4 \mathrm{mg} / \mathrm{mL}$ solution in chloroform.

\subsection{Plant Material}

Aerial parts of Peperomia scandens Ruiz \& Pavon were collected in Rio de Janeiro, RJ, Brazil in 2003. Dr. Elsie Franklin Guimarães performed identification of this plant material and a voucher specimen (RB 323492) was deposited in the Herbarium of the Botanical Garden Research Institute from Rio de Janeiro, Brazil. 


\subsection{Extraction and Isolation}

The fresh aerial parts of $P$. scandens $(1 \mathrm{~kg}$ ) were subjected to hydrodistillation on a Clevenger-type apparatus for $2 \mathrm{~h}$, to yield $750 \mathrm{mg}$ of a pale yellow crude oil, which was immediately submitted to analysis through GC-FID and GC-MS. $735 \mathrm{mg}$ of this oil was submitted to column chromatography on silica gel eluted with a gradient of Hex/EtOAc yielding compound $1(280 \mathrm{mg})$, which proved to be practically pure by GC-FID and GC-MS analyses. Melting point: $62-64{ }^{\circ} \mathrm{C}$ (literature $62-64{ }^{\circ} \mathrm{C}$, CAS register 28895-15-0), carried out on a Fisatom 430 (Fisatom, São Paulo, Brazil). Specific Rotation $[\alpha]_{\mathrm{D}}{ }^{30}$ : $+78^{\circ}\left(\mathrm{c} 0,35 \mathrm{CHCl}_{3}\right.$ ), carried out on a Jasco Brasil P-200 polarimeter (Jasco Brasil, São Paulo, Brazil).

\section{Conclusions}

Based on extensive analyses of experimental data and on the quite perfect agreement between calculated and experimental (fingerprint region) infrared spectra and ${ }^{13} \mathrm{C}-\mathrm{NMR}$ chemical shifts, the structure of a natural product isolated from aerial parts of $P$. scandens was unambiguously determined as 3-ishwarone, previously isolated by Lago et al. from another Peperomia species, P. oreophila. Its absolute configuration is under investigation in our laboratories.

\section{Supplementary Materials}

Supplementary materials including additional IR and NMR spectral data can be accessed at: http://www.mdpi.com/1420-3049/18/11/13520/s1.

\section{Acknowledgments}

We wish to thank to CNPq and FAPERJ for financial support.

\section{Conflicts of Interest}

The authors declare no conflict of interest.

\section{References}

1. Mathieu, G.; Samain, M.-S.; Reynders, M.; Goetghebeur, P. Taxonomy of the Peperomia species (Piperaceae) with pseudo-epiphyllous inflorescences, including four new species. Bot. J. Linn. Soc. 2008, 157, 177-196.

2. López, S.N.; Lopes, A.A.; Batista, J.M., Jr.; Flausino, O., Jr.; Bolzani, V.S.; Kato, M.J.; Furlan, M. Geranylation of benzoic acid derivatives by enzymatic extracts from Piper crassinervium (Piperaceae). Bioresour. Technol. 2010, 101, 4251-4260.

3. Felippe, L.G.; Batista, Jr., J.M.; Baldoqui, D.C.; Nascimento, I.R.; Kato, M.J.; He, Y.; Nafie, L.A.; Furlan, M. VCD to determine absolute configuration of natural product molecules: secolignans from Peperomia blanda. Org. Biomol. Chem. 2012, 10, 4208-4214.

4. Li, Y.-Z.; Tong, A.-P.; Huang, J. Two New Norlignans and a New Lignanamide from Peperomia tetraphylla. Chem. Biodivers. 2012, 9, 769-776. 
5. Salazar, K.J.M.; Lago, J.H.G.; Guimarães, E.F.; Kato, M.J. Meroterpenes from Peperomia oreophila Hensch. and Peperomia arifolia Miq. J. Braz. Chem. Soc. 2012, 23, 782-785.

6. Velozo, L.S.M.; Ferreira, M.J.P.; Santos, M.I.S.; Moreira, D.L.; Emereciano,V.P.; Kaplan, M.A.C. Unusual chromenes from Peperomia blanda. Phytochemistry 2006, 67, 492-496.

7. Velozo, L.S.M.; Ferreira, M.J.P.; Santos, M.I.S.; Moreira, D.L.; Guimarães, E.F.; Emerenciano, V.P.; Kaplan, M.A.C. C-glycosyl flavones from Peperomia blanda. Fitoterapia 2009, 80, 119-122.

8. Wang, Q.W.; Yu, D.H.; Lin, M.G.; Zhao, M.; Zhu, W.J.; Lu, Q.; Li, G.X.; Wang, C.; Yang, Y.F.; Qin, X.M.; et al. Antiangiogenic Polyketides from Peperomia dindygulensis Miq. Molecules 2012, 17, 4474-4483.

9. Aziba, P.I.; Adedeji, A.; Ekor, M.; Adeyemi, O. Analgesic activity of Peperomia pellucida aerial parts in mice. Fitoterapia 2001, 72, 57-58.

10. Pinheiro, B.G.; Silva, A.S.B.; Souza, G.E.P.; Figueiredo, J.G.; Cunha, F.Q.; Da Silva, J.K.R.; Maia, J.G.S.; Sousa, P.J.C. Chemical composition, Antinociceptive and anti-inflammatory effects in rodents of the essential oil of Peperomia serpens (Sw.) Loud. J. Ethnopharmacol. 2011, 138, 479-486.

11. Holthe, P.A.; Sternberg Lda, S.; Ting, I.P. Developmental Control of CAM in Peperomia scandens. Plant Physiol. 1987, 84, 743-747.

12. Lago, J.H.G.; Oliveira, A.; Guimarães, E.F.; Kato, M.J. 3-Ishwarone and 3-Ishwarol, Rare sesquiterpenes in essential oil from leaves of Peperomia oreophila Hensch. J. Braz. Chem. Soc. 2007, 18, 638-642.

13. Fraga, B.M. Natural sesquiterpenoids. Nat. Prod. Rep. 2012, 29, 1334-1366.

14. Hanwell, M.D.; Curtis, D.E.; Lonie, D.C.; Vandermeersch, T.; Zurek, E.; Hutchison, G.R. Avogadro: An advanced semantic chemical editor, visualization, and analysis platform. J. Cheminformatics 2012, 4, 17.

15. Frisch, M.J.; Trucks, G.W.; Schlegel, H.B.; Scuseria, G.E.; Robb, M.A.; Cheeseman, J.R.; Scalmani, G.; Barone, V.; Mennucci, B.; Petersson, G.A.; Nakatsuji, H.; Caricato, M.; Li, X.; Hratchian, H.P.; Izmaylov, A.F.; Bloino, J.; Zheng, G.; Sonnenberg, J.L.; Hada, M.; Ehara, M.; Toyota, K.; Fukuda, R.; Hasegawa, J.; Ishida, M.; Nakajima, T.; Honda, Y.; Kitao, O.; Nakai, H.; Vreven, T.; Montgomery, J.A., Jr.; Peralta, J.E.; Ogliaro, F.; Bearpark, M.; Heyd, J.J.; Brothers, E.; Kudin, K.N.; Staroverov, V.N.; Kobayashi, R.; Normand, J.; Raghavachari, K.; Rendell, A.; Burant, J.C.; Iyengar, S.S.; Tomasi, J.; Cossi, M.; Rega, N.; Millam, N.J.; Klene, M.; Knox, J.E.; Cross, J.B.; Bakken, V.; Adamo, C.; Jaramillo, J.; Gomperts, R.; Stratmann, R.E.; Yazyev, O.; Austin, A.J.; Cammi, R.; Pomelli, C.; Ochterski, J.W.; Martin, R.L.; Morokuma, K.; Zakrzewski, V.G.; Voth, G.A.; Salvador, P.; Dannenberg, J.J.; Dapprich, S.; Daniels, A.D.; Farkas, Ö.; Foresman, J.B.; Ortiz, J.V.; Cioslowski, J.; Fox, D.J. Gaussian 09, Revision A.01; Gaussian, Inc.: Wallingford, CT, USA, 2009.

16. Costa, F.L.P.; de Albuquerque, A.C.F.; dos Santos, F.M.; de Amorim, M.B. GIAO-HDFT scaling factor for 13C NMR chemical shifts calculation. J. Phys. Org. Chem. 2010, 23, 972-977.

17. Cimino, P.; Gomez-Paloma, L.; Duca, D.; Riccio, R.; Bifulco, G. Comparison of different theory models and basis sets in the calculation of 13C NMR chemical shifts of natural products. Magn. Reson. Chem. 2004, 42, S26-S33. 
18. Adamo, C.; Barone, V. Exchange functionals with improved long-range behavior and adiabatic connection methods without adjustable parameters: The mPW and mPW1PW models. J. Chem. Phys. 1998, 108, 664-675.

19. Perdew, J.P.; Burke, K.; Wang, Y. Generalized gradient approximation for the exchangecorrelation hole of a many-electron system. Phys. Rev. B 1996, 54, 16533-16539.

20. Haharan, P.C.; Pople, J.A. The influence of polarization functions on molecular orbital hydrogenation energies. Theor. Chim. Acta 1973, 28, 213-222.

21. Costa, F.L.P.; de Albuquerque, A.C.F.; Borges, R.M.; dos Santos, Jr., F.M.; de Amorim, M.B. High cost-effectiveness ratio: GIAO-MPW1PW91/6-31G(d)//MPW1PW91/6-31G(d) scaling factor for ${ }^{13} \mathrm{C}$ nuclear magnetic resonance chemical shifts calculation. J. Comp. Theor. Nanosci. 2014, 11, 219-225.

22. Becke, A.D.J. Density-functional thermochemistry. III. The role of exact exchange. Chem. Phys. 1993, 98, 5648-5652.

23. Lee, C.; Yang, W.; Parr, R.G. Development of the Colle-Salvetti correlation-energy formula into a functional of the electron density. Phys. Rev. B 1988, 37, 785-789.

24. Vosko, S.H.; Wilk, L.; Nusair, M. Accurate spin-dependent electron liquid correlation energies for local spin density calculations: a critical analysis. Can. J. Phys. 1980, 58, 1200-1211.

25. Dunning, Jr., T.H. Gaussian basis sets for use in correlated molecular calculations. I. The atoms boron through neon and hydrogen. J. Chem. Phys. 1989, 90, 1007-1023.

26. Sinha, P.; Boesch, S.E.; Changming, G.; Wheeler, R.A.; Wilson, A.K. Harmonic vibrational frequencies: Scaling factors for hf, b3lyp, and mp2 methods in combination with correlation consistent basis sets. J. Phys. Chem. A 2004, 108, 9213-9217.

27. Busch, K.W.; Busch, M.A. Chiral Analisys, 1st ed.; Elsevier: Amsterdam, the Netherlands, 2006; pp. 461-504.

Sample Availability: Not available.

(C) 2013 by the authors; licensee MDPI, Basel, Switzerland. This article is an open access article distributed under the terms and conditions of the Creative Commons Attribution license (http://creativecommons.org/licenses/by/3.0/). 